\title{
Characterization of Phosphate Glass Reinforced Gelatin Blend Bioactive Composite Films
}

\author{
Kamol Dey ${ }^{1, *}$, Poonam Alamgir ${ }^{2,3}$, Shahnaz Parvin ${ }^{2,3}$, Gulshana Mohol ${ }^{2,3}$, Wafa Tonny ${ }^{2}$, \\ Mubarak A. Khan ${ }^{2}$ and Ruhul A. Khan ${ }^{2}$ \\ ${ }^{1}$ Department of Applied \& Environmental Chemistry, Faculty of Science, University of Chittagong, Chittagong- \\ 4331, Bangladesh \\ ${ }^{2}$ Institute of Radiation and Polymer Technology, Bangladesh Atomic Energy Commission, Savar, Dhaka \\ 1000, Bangladesh \\ ${ }^{3}$ Department of Chemistry, Jahangirnagar University, Savar, Dhaka, Bangladesh
}

\begin{abstract}
Bioactive composite films were prepared using bioresorbable phosphate glass powder and biodegradable polymer gelatin $(G)$ through solution casting process. Biocompatible monomer, 2-hydroxyethyl methacrylate (HEMA) was used as the cross-linking agent and bioresorbable phosphate glass (PG) powder was used as reinforcement filler. The composite films were obtained at various ratios of G, PG and HEMA. The PG modified gelatin composite (PG/G) film was fabricated at a weight ratio of 12:88 while HEMA modified gelatin composite (HEMA/G) film at 50:50 ratio. On the other hand, hybrid gelatin composite film, containing both PG and HEMA, was obtained using a G/PG/HEMA ratio of 44:12:44. Incorporation of PG improved the mechanical properties of the composite films. Morphological property of the composite films was investigated by stereo microscope and it revealed that the composite films were porous in nature. The thermal behaviour of the films was studied using thermogravimetric analysis. Water uptake of the films was also performed.
\end{abstract}

Keywords: Gelatin, phosphate glass, bioactive, composite films, stereo microscope.

\section{INTRODUCTION}

Bioresorbable composite has gained tremendous interest in the field of biomaterial research. Tissue engineering has brought new challenges in this field in terms of biodegradability, biocompatibility, homogeneity, osteoconductivity, vascularity, cell proliferation, controlled release, mechanical properties [1-3]. Both natural and synthetic polymers along with polylactic acid, polyglycolide, polycaprolactone and their copolymers, hydroxyapatite, calcium phosphate, hyaluronate and hyaluronate derivatives have been thoroughly studied to find a novel class of potential application in tissue engineering [4-6]. Polymer blending technique is simple and efficient to improve the properties of polymer up to a desired level and has been widely utilized in polymer modification field. It offers reduced processing cost and versatility in the selection of materials [7]. Polymer blending of compatible materials leads to substantial enhancement of mechanical and thermal performance [8-10]. A range of materials with different properties can be successfully blended to obtain fine tunable material for a particular application [11]. Various nano-reinforcement fillers such as silicate clay, carbon nanotubes,

*Address correspondence to this author at the Department of Applied \& Environmental Chemistry, Faculty of Science, University of Chittagong, Chittagong-4331, Bangladesh; Tel: +88-031-2606001-10, 716552;

Fax:+88-031-2606014; E-mail: kamolacct@gmail.com, kamoldey@cu.ac.bd graphene, calcium carbonate and phosphate glass are being extensively studied in the field of nanocomposites. These nano fillers are capable of enhancing the mechanical and thermal performance of the polymer [12]. Our present research aims at developing a biopolymer-organic-inorganic blend composite film with enhanced mechanical and thermal properties. In the present work, we chose phosphate based glass $\left(20 \mathrm{Na}_{2} \mathrm{O}-24 \mathrm{CaO}-16 \mathrm{MgO}-40 \mathrm{P}_{2} \mathrm{O}_{5}\right)$ as a reinforcement filler because of its some important criteria regarding biomedical applications [13, 14]. The dissolution rate of the glass can be altered varying the composition to tailor the biomedical properties. The $\mathrm{P}_{2} \mathrm{O}_{5}$ provides the backbone structure of phosphate glass and has been evolved as a promising biomaterial $[15,16]$. The organic phase of hard tissues contains type I collagen $[17,18]$. Gelatin is a denatured collagen and possesses a wide range of biomedical properties making suitable for tissue engineering $[19,20]$. In the present study, HEMA is used as a hydrophilic biocompatible monomer. HEMA is a hydrophilic monomer and is using in biomedical field [21]. Poly(HEMA) has also adequate biocompatibility and uses in medical science as implant [22]. The goal of this research work is to determine the influence of $P G$ and HEMA on the preparation of a bio-artificial polymeric material using gelatin polymer that would be used as an excellent alternative to tissue scaffold material for artificial bone tissue engineering and drug delivery. 


\section{EXPERIMENTAL}

\subsection{Materials}

Gelatin (pharmaceutical grade) was collected from the Opsonin Pharma Limited, Bangladesh. Phosphate glass (molecular formula: $20 \mathrm{Na}_{2} \mathrm{O}-24 \mathrm{CaO}-16 \mathrm{MgO}-$ $40 \mathrm{P}_{2} \mathrm{O}_{5}$ ) used in this study was supplied by the Department of Mechanical, Materials and Manufacturing Engineering, University of Nottingham, UK. Monomer HEMA (molecular weight: 130.14, melting point: $-12{ }^{\circ} \mathrm{C}$, boiling point: $205{ }^{\circ} \mathrm{C}$, miscible in water) was purchased from Fluka Chemie AG, $\mathrm{CH}-9470$ Buchs.

\subsection{Preparation of Blend Composite Films}

Accurately weighed gelatin/phosphate glass/HEMA was dissolved in slightly hot water to form solution. The blending mixture was continuously stirred manually to aid formation of homogenous mixture and heated for about one and half an hour. The solution was finally cast on the plastic covered glass plate to form thin composite film. The solution layer was maintained into a thickness of about $0.50 \mathrm{~mm}$ on the glass plate. It was then dried in room temperature for about 48 hours. The dried composite films were peeled off and subjected to characterization studies. The composition of the materials studied is listed in the Table 1. Experimental flow diagram is presented in the Figure 1. Figures 2a-c depict the preparation of G/PG/HEMA blend solution by mechanical mixing, a composite film and sample prepared for test, respectively.

\subsection{Mechanical Property of the Composite Films}

Mechanical properties such as tensile strength (TS), tensile modulus (TM), and elongation at break (Eb\%) of the films were investigated by the Universal Testing Machine (Hounsfield series $S$ testing machine, H50 KS-0404) with a crosshead speed of $1 \mathrm{~mm}$ per second at a span distance of $25 \mathrm{~mm}$. The dimensions of the test specimen were $60 \mathrm{~mm} \times 10 \mathrm{~mm} \times 0.02 \mathrm{~mm}$. The experiment was carried out according to the European standard (ISO/DIS 527-1:2010).
2.4. Water Uptake (\%) Profile of the Composite Films

The water uptake of the composite films was periodically $(15,30,45,60 \mathrm{sec})$ monitored up to $60 \mathrm{sec}$ to find the water uptake nature of the composite films. Percentage water uptake was determined relative to the dry weight of the sample.

\subsection{Thermal Characterization of the Composite Films}

Various thermal properties like onset, offset and glass transition temperature of the samples were measured using thermo-mechanical analyzer (TMA) (Linseis TMA/DMA L77, USA). Figure $\mathbf{3 b}$ shows a TMA machine.

\subsection{Morphological Characteristics of the Composite Film}

The surface morphology of G/PG composite film was determined by stereo microscope (SM).

\section{RESULTS AND DISCUSSIONS}

The data presented in the manuscript are average values of at least five samples and the results obtained are within the accuracy of $\pm 1 \%$.

\subsection{Mechanical Analysis of the Composite Films}

Tensile property is of great importance to find the suitability of diversified application of a polymeric material. The mechanical properties of the pure and composite gelatin films were tabulated in the Table 2. For each test, five samples were characterized. The values presented here is the average of five samples.

From the Table 2, it was observed that, incorporation of PG increased TS value while as TM value and $\mathrm{Eb} \%$ were reduced. The TS, TM and $\mathrm{Eb} \%$ of the pure gelatin were found to be $28 \mathrm{MPa}, 846 \mathrm{MPa}$ and $20 \%$, respectively. On the other hand, for the G/PG composite film, the TS, TM and Eb\% were obtained 36

Table 1: Composition (w/w \%) of Different Composite Films

\begin{tabular}{|c|c|c|c|}
\hline Composite Formulation & Gelatin (wt \%) & Phosphate Glass (wt \%) & HEMA (wt \%) \\
\hline \hline G & 100 & 0 & 0 \\
\hline G/PG & 88 & 12 & 50 \\
\hline G/HEMA & 50 & 12 & 44 \\
\hline G/PG/HEMA & 44 & 0 & 0 \\
\hline
\end{tabular}




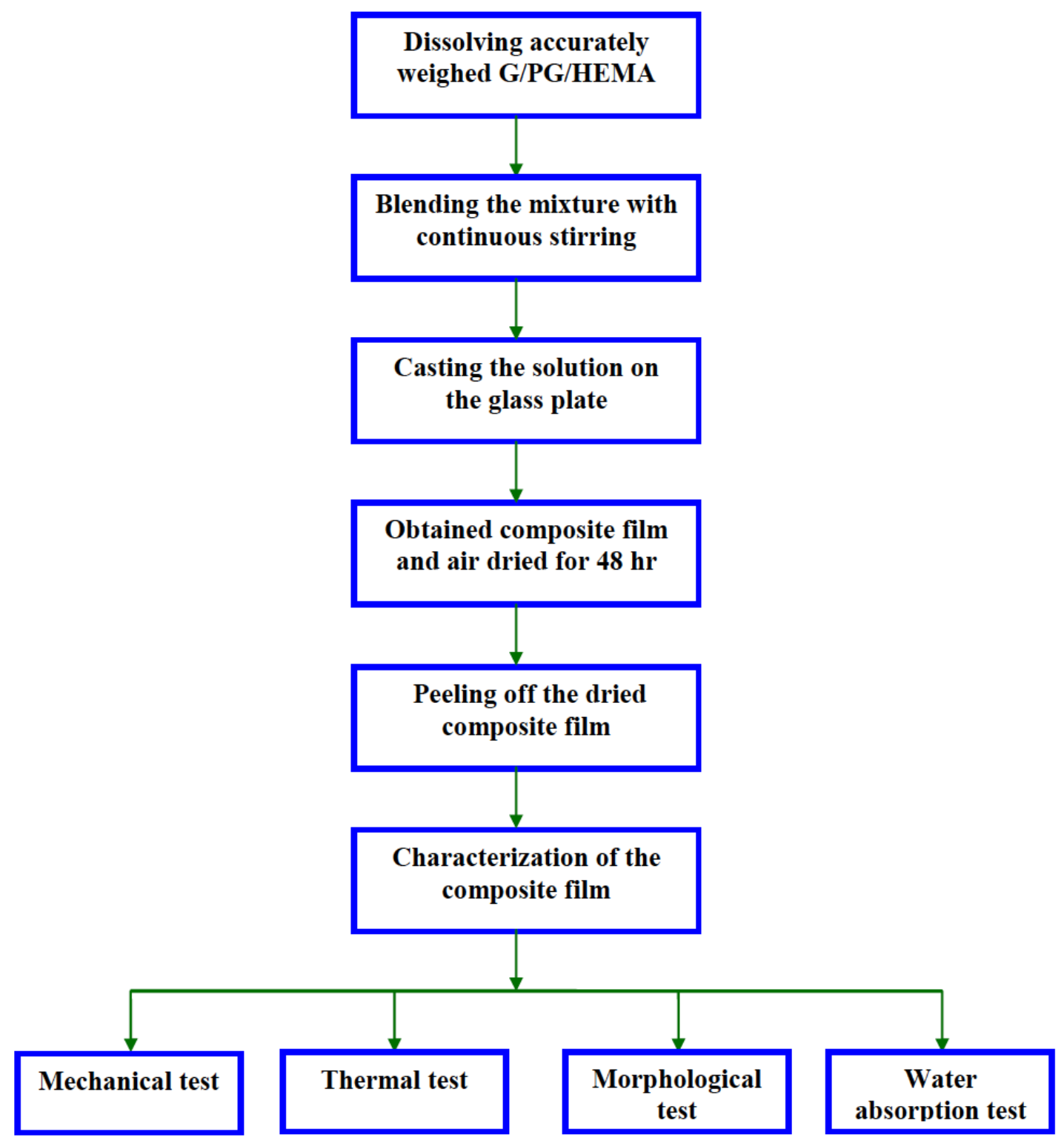

Figure 1: Experimental flow diagram.

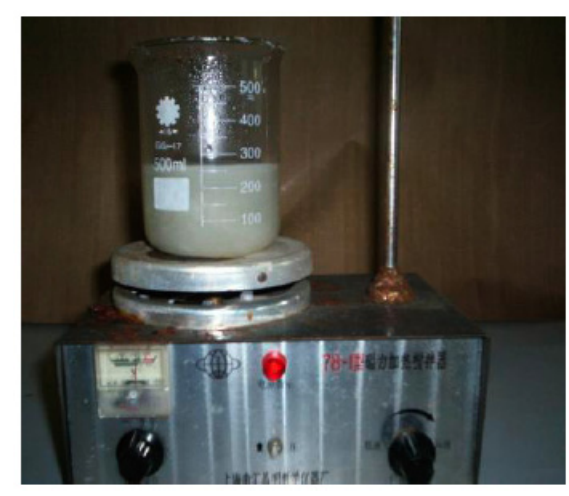

(a)

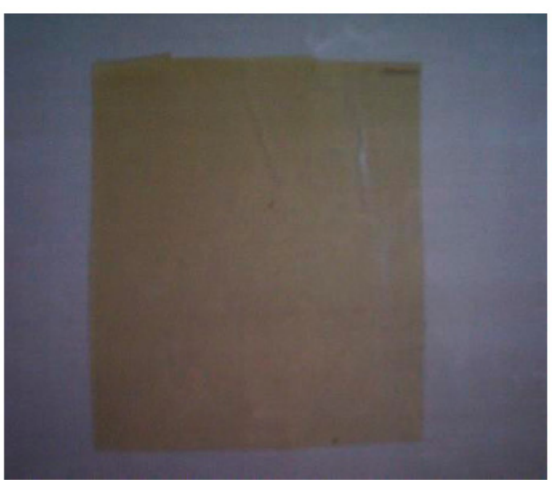

(b)

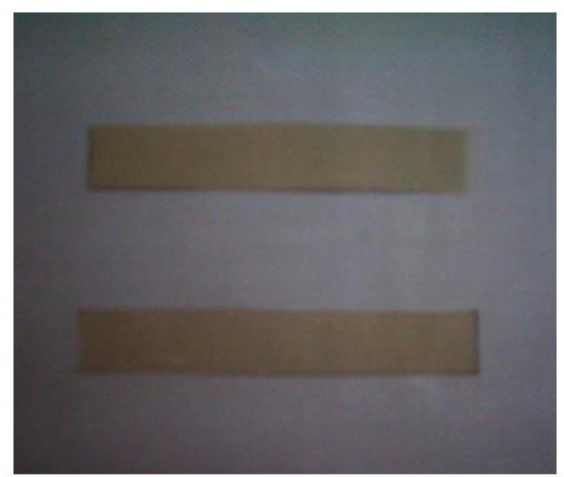

(c)

Figure 2: (a): Preparation of G/PG/HEMA blend solution by mechanical mixing; 2 (b): A composite film; and 2 (c): Prepared sample for test. 


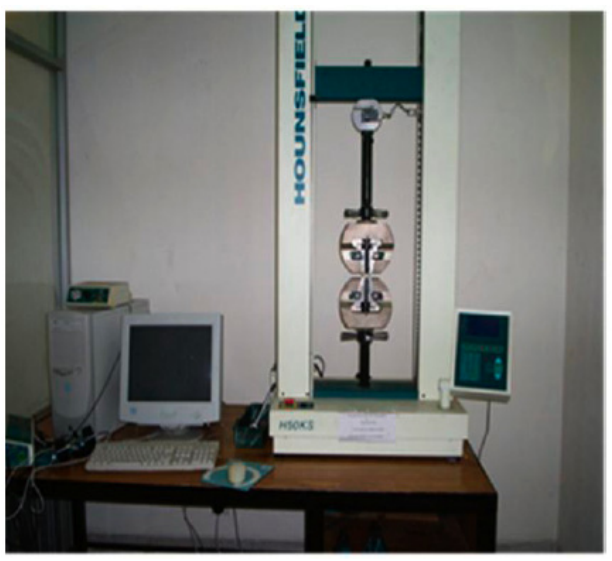

(a)

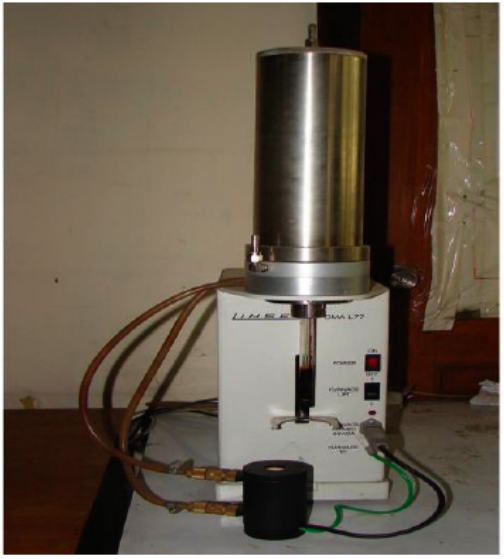

(b)

Figure 3: (a): Universal Testing Machine; and 3 (b): Thermo-mechanical Analyzer (TMA).

Table 2: Tensile Strength, Tensile Modulus and Elongation at Break (\%) of Different Composite Films

\begin{tabular}{|c|c|c|c|}
\hline Sample Name & Tensile Strength (MPa) & Tensile Modulus (MPa) & Elongation at Break (\%) \\
\hline \hline G & 28 & 846 & 20 \\
\hline G/PG & 36 & 266 & 13 \\
\hline G/HEMA & 31 & 62 & 156 \\
\hline G/PG/HEMA & 19 & 36 & 120 \\
\hline
\end{tabular}

$\mathrm{MPa}, 266 \mathrm{MPa}$ and $13 \%$, respectively. The improved TS may be due to the mechanical interlocking of the PG fillers with gelatin [23]. Moreover, metallic structure phosphate glass stiffs the gelatin film which increased TS value but reduced Eb\%. Figures 4, 5 and $\mathbf{6}$ show the comparison of tensile strength, tensile modulus and elongation at break (\%) among different composite films, respectively. Addition of PG improved $29 \%$ TS value (36 MPa) of G/PG composite film compared to pure gelatin film. Similarly, incorporation of HEMA increased TS and $\mathrm{Eb} \%$ to $11 \%$ and $680 \%$, respectively, with respect to pure gelatin film, but TM value was decreased to $62 \mathrm{MPa}$. HEMA imparts significant flexibility to the composite film. The increased of TS and $\mathrm{Eb} \%$ may be due to the grafting or cross-linking of the HEMA molecules with gelatin polymer chain [24]. However, G/PG/HEMA composite film showed reduced TS and TM values which were $19 \mathrm{MPa}$ and $36 \mathrm{MPa}$, respectively. Presence of HEMA disturbs the homogeneous distribution of $P G$ into gelatin matrix and hence reduced mechanical interlocking promotes poor filler/matrix interaction. Similarly, PG imparts more water resistant P-O-P bonds reducing the availability of $-\mathrm{OH}$ groups in gelatin to interact with the $-\mathrm{OH}$ groups of HEMA [21]. These two phenomena may be responsible to reduced mechanical properties when PG and HEMA are both present in the gelatin film. This study revealed that, introduction of both $P G$ and HEMA into gelatin did not show any synergism effect on mechanical properties. Rather, PG incorporation provided improved tensile property.

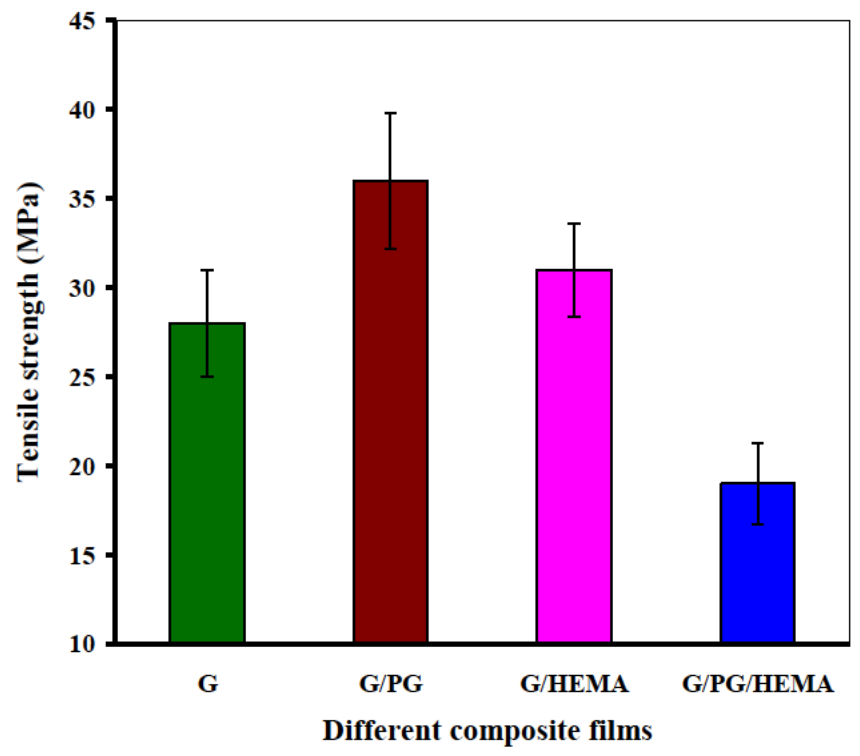

Figure 4: Comparison of tensile strength among different composite films. 


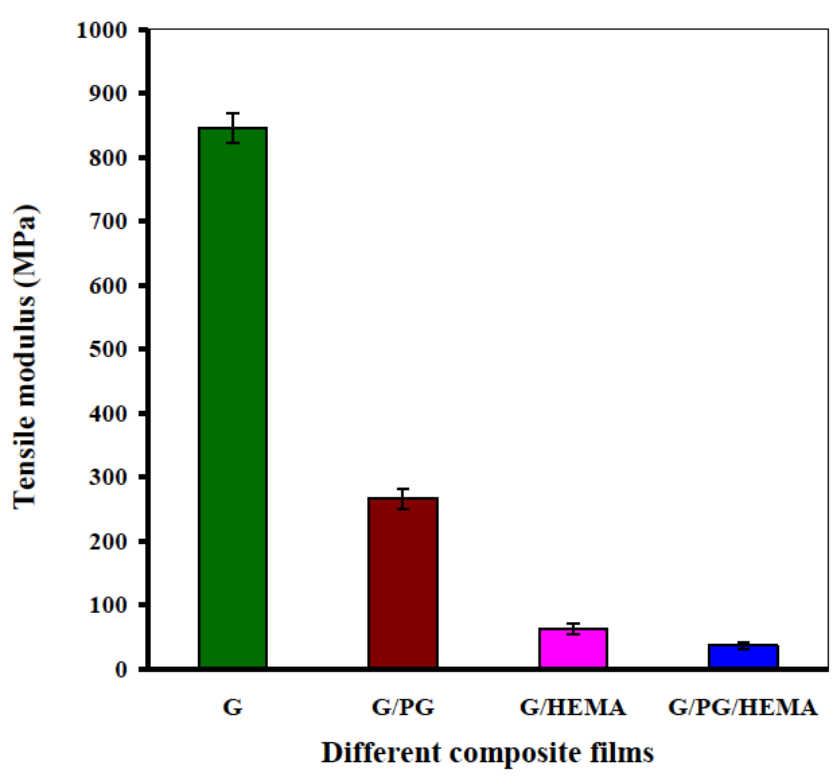

Figure 5: Comparison of tensile modulus among different composite films.

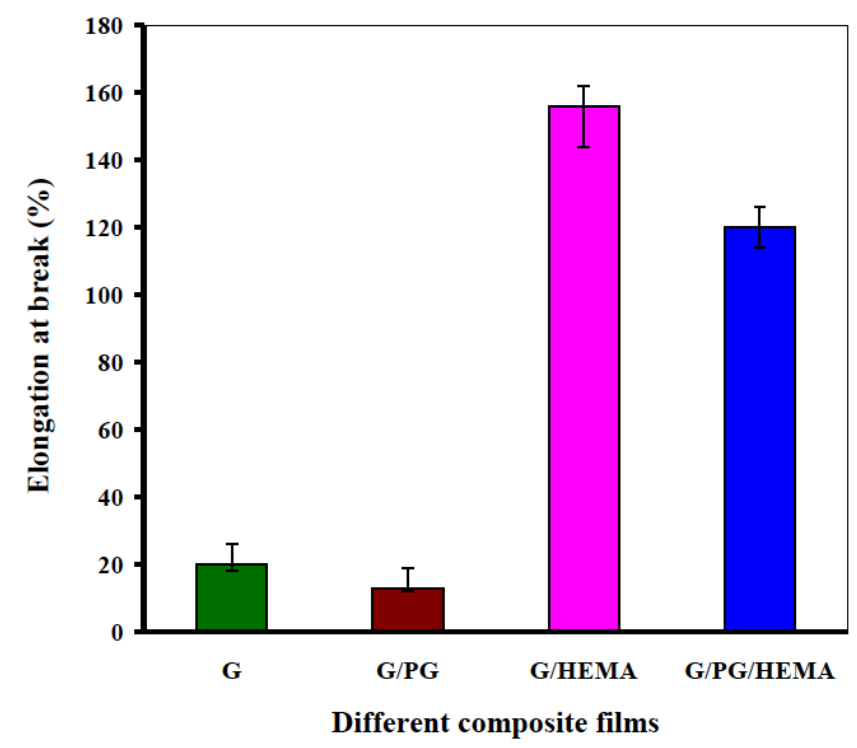

Figure 6: Comparison of elongation at break (\%) among different composite films.

\subsection{Investigation of Failure Modes by Stress-Strain Curves}

To investigate the fracture modes of the prepared films, the stress-strain curves were studied. The strain-stress curves for G, G/PG, G/HEMA, and G/PG/HEMA based films are presented in Figure 7. Gelatin film exhibited intensive stress $(56 \mathrm{~N})$ within a few $\mathrm{mm}$ of strain $(5 \mathrm{~mm})$ which indicated the rigid nature of the film. Similarly, addition of phosphate glass in gelatin film showed more stiffness. After $3 \mathrm{~mm}$ of strain, G/PG films reached to $76 \mathrm{~N}$ of stress. Addition of $P G$ in the gelatin film is clearly reveled that gelatin film was successfully reinforced with $P G$ powder during casting process. Both gelatin and phosphate glass reinforced gelatin films showed sharp peaks and indicated very low elongation of break that was described in Figure 6. On the other hand, HEMA treated gelatin (G/HEMA) film showed the maximum stress $(62 \mathrm{~N})$ after $30 \mathrm{~mm}$ of strain then film fractured at $40 \mathrm{~mm}$. Similarly, the film G/PG/HEMA exhibited a long strain $(30 \mathrm{~mm})$ and but less stress $(42 \mathrm{~N})$. From this investigation, this is clear that phosphate glass powder acted as a good reinforcing agent and HEMA monomer provided flexibility to the films. Similar type of stressstrain observations are reported elsewhere [25]. It is to be mentioned that polymers are classified into three types according to the type of stress-strain curves. In brittle polymers such as polystyrene, the stress-strain curves are linear up to the fracture point. Here, $G$ and G/PG exhibited brittle nature. Tough polymers such as polyethylene exhibit a yield point followed by extensive elongation at almost constant stress. The films of G/HEMA and G/PG/HEMA showed the nature of tough polymer like polyethylene. The third type of stressstrain curve is exhibited by elastomers such as polyurethane, in which a nonlinear curve up to break point, and the elongation percentage may be of the order of several hundred percent [25].

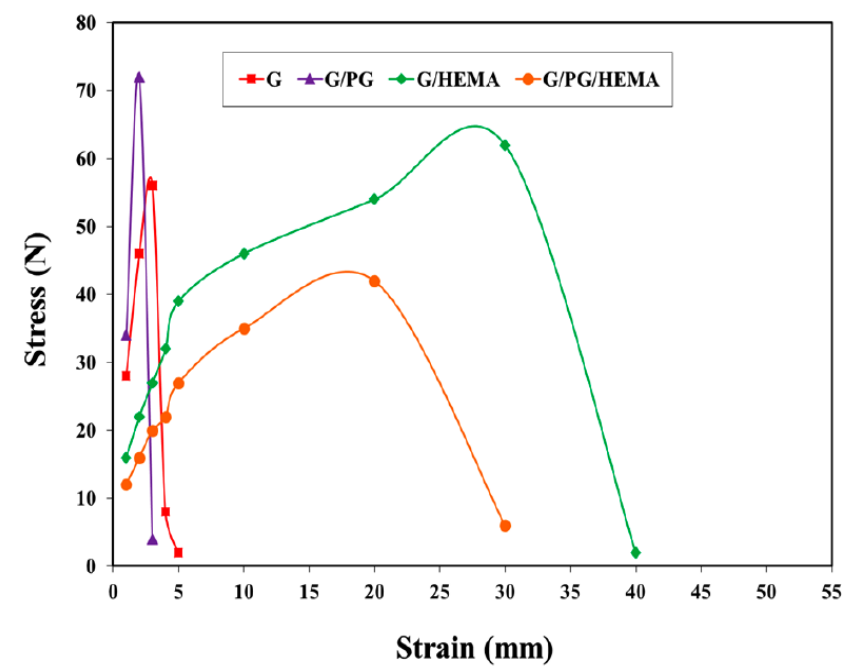

Figure 7: Stress-strain curve of Gelatin (G), GelatinPhosphate Glass (G/PG), Gelatin-HEMA and GelatinPhosphate Glass-HEMA (G/PG/HEMA).

\subsection{Thermal Analysis (TMA) of the Composite Films}

The glass transition temperature $\left(T_{g}\right)$ was investigated by thermomechanical analysis. Figure 8 shows $T_{g}$ of the different composite films. The highest $T_{g}$ was obtained for G/PG composite film. 
Table 3: Thermal Properties of Different Composite Films

\begin{tabular}{|c|c|c|c|}
\hline Sample Name & Onset Temperature $\left({ }^{\circ} \mathrm{C}\right)$ & Glass Point $\left({ }^{\circ} \mathrm{C}\right)$ & Offset Temperature $\left({ }^{\circ} \mathrm{C}\right)$ \\
\hline \hline G & 40.8 & 44.9 & 50.4 \\
\hline G/PG & 66.1 & 66.2 & 69.7 \\
\hline G/HEMA & 31.6 & 32.6 & 37.0 \\
\hline G/PG/HEMA & 36.0 & 38.7 & 43.5 \\
\hline
\end{tabular}

The glass transition point of pure gelatin was found $44.9^{\circ} \mathrm{C}$ whereas it was $32.6^{\circ} \mathrm{C}$ for $\mathrm{G} / \mathrm{HEMA}, 66.2^{\circ} \mathrm{C}$ for $\mathrm{G} / \mathrm{PG}$ and $38.7^{\circ} \mathrm{C}$ for $\mathrm{G} / \mathrm{PG} / \mathrm{HEMA}$ composite films. The changed in morphology as well as better fillermatrix interaction might have changed the $T_{g}$.

From the Table 3 , it is seen that the G/PG composite film showed the highest onset, offset and glass transition value. The incorporation of fillers usually increased $T_{g}$ of the composites. The improved $T_{g}$ may be ascribed due to the restriction of mobility of the polymer chain resulted from the better filler-matrix interaction $[26,27]$.

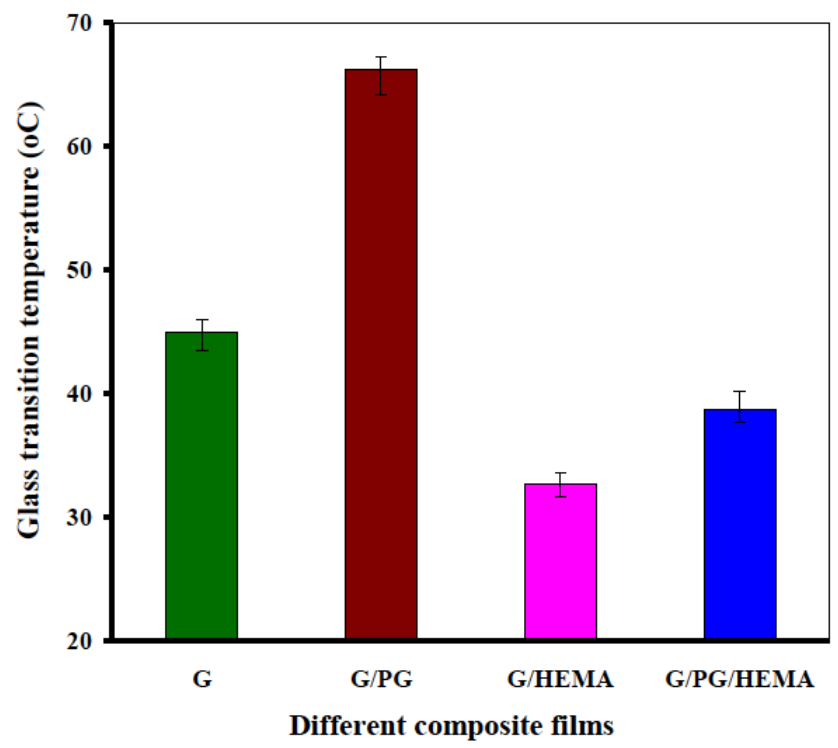

Figure 8: Comparison of glass transition temperature $\left(T_{g}\right)$ among different composite films.

\subsection{Water Uptake (\%) Characteristics of the Composite Films}

The samples were immersed into deionized water for a set period of time. The samples were then removed from water after set time interval and their wet weight were measured immediately after tenderly wiping their surfaces. The amount of water uptake was calculated dividing weight difference between the wet and dry sample by the weight of dry sample. Water absorption of the composite films against total soaking time (sec) was presented in the Figure 9. The maximum water uptake was observed for pure gelatin film, as expected, due to the presence of higher amount of hydrophilic $-\mathrm{OH}$ groups. The G/PG composite films had moderately water uptake reaching value $4 \%$ after $60 \mathrm{sec}$ soaking time. Incorporation of phosphate glass induces more water resistant P-O-P bonds which reduces the strong hydrophilic nature of gelatin [28]. A slight lower water uptake was shown by the G/PG/HEMA composite films compared to G/PG film. This may be due to the presence of cross-linking [29] and water resistant P-O-P bonds as well as lesser amount of $-\mathrm{OH}$ groups.

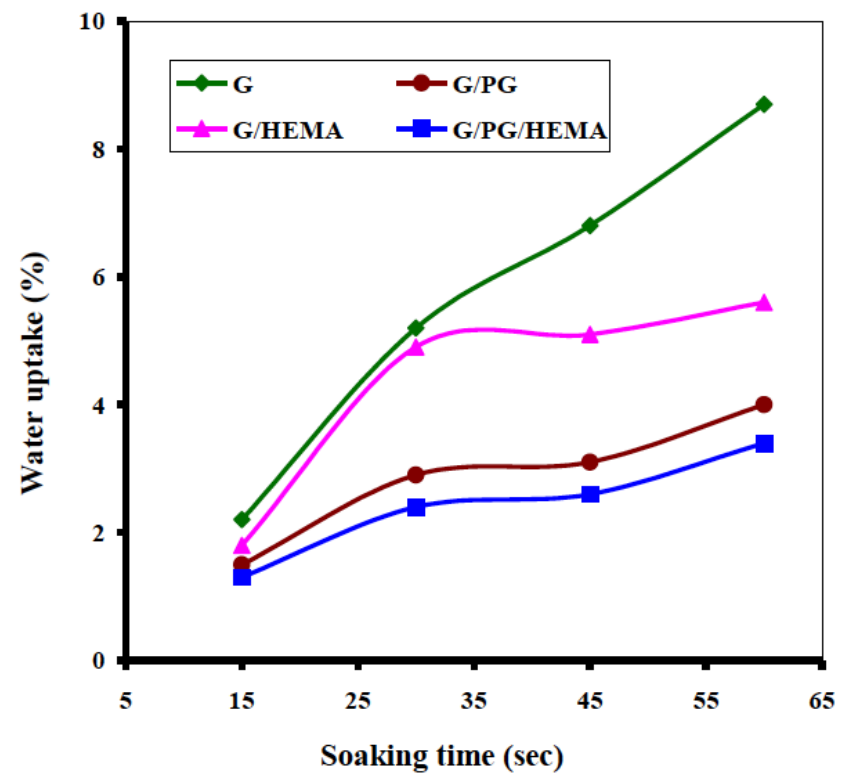

Figure 9: Percentage water uptake of the different composite films against soaking time (sec).

\subsection{Morphology of the Composite Films}

The pore morphology of the G/PG composite films was studied using stereo microscope. The stereo micrograph of the G/PG composite film was presented in the Figure 10. A dissimilar vascular shape pore structures was observed in the composite film. The distribution of pores was not uniform. Presence of 
phosphate glass was responsible to create these pores in the composite film. The distribution nature of $P G$ inside the gelatin polymer matrix demonstrates low dispersion quality. Cluster size pores inside the bulk sample may be due to the high loading percentage of PG (12 wt \%) into the gelatin matrix.

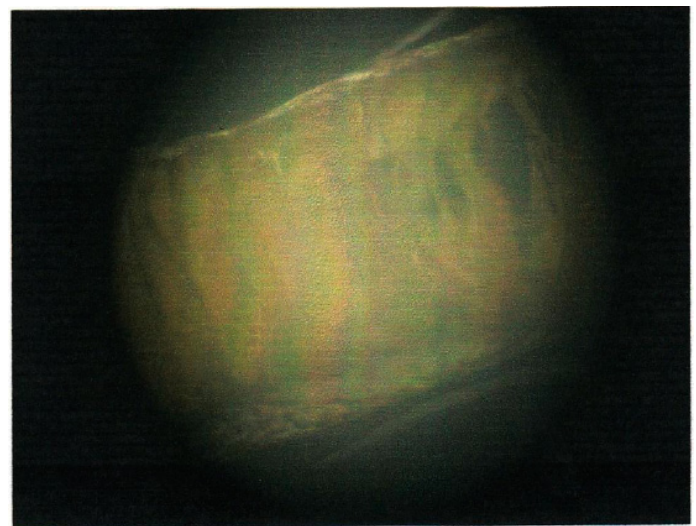

Figure 10: Stereo micrograph of the G/PG composite film.

\section{CONCLUSION}

Gelatin and phosphate glass based biocomposite films were developed using biopolymer, gelatin and bioresorbable phosphate glass powder. The incorporation of phosphate glass into gelatin showed improved tensile and thermal properties. Stereo micrograph revealed porous structures of the composite films. Moreover, the degradation behavior of the composite films can be controlled by changing the amount of phosphate glass powders. The fabricated porous bio-composite films have the potential to be used in biomedical and tissue engineering applications.

\section{REFERENCES}

[1] Babu RP, O'Connor K, Seeram R. Current progress on biobased polymers and their future trends. Prog Biomat 2013; 2 : 1-16. http://www. progressbiomaterials.com/content/2/1/8

[2] Chen Q. Biomaterials for bone tissue engineering. MK Danquah, RI Mahato (eds.), Emerging Trends in Cell and Gene Therapy 2013; 23: 563-94.

http://doi.org/10.1007/978-1-62703-417-3 23

[3] Sawaengsak C, Mori Y, Yamanishi K, Mitrevej A, Sinchaipanid N. Chitosan nanoparticle encapsulated hemagglutinin-split influenza virus mucosal vaccine. AAPS PharmSciTech 2013; 15: 317-25. http://doi.org/10.1208/s12249-013-0058-7

[4] Wu CJ, Gaharwar AK, Schexnailder PJ, Schmidt G. Development of biomedical polymer-silicate nanocomposites: A materials science perspective. Materi 2010; 3: 2986-3005. http://dx.doi.org/10.3390/ma3052986

[5] Martino VP, Pollet E, Avérous L. Novative biomaterials based on chitosan and poly( $\varepsilon$-caprolactone): Elaboration of porous structures. J Polym Environ 2011; 19: 819-26. http://doi.org/10.1007/s10924-011-0354-9
[6] Park DH, Hwang SJ,Oh JM,Yang JH, Choy JH. Polymerinorganic supramolecular nanohybrids for red, white, green, and blue applications. Prog Polym Sci 2013; 38: 1442- 86. http://dx.doi.org/10.1016/j.progpolymsci.2013.05.007

[7] Liu X, Fan XD, Tang MF Nie Y. Synthesis and characterization of core-shell acrylate based latex and study of its reactive blends. Int J Mol Sci 2008; 9: 342-54. http://dx.doi.org/10.3390/ijms 9030342

[8] Mathura V, Sharmab K. Structural, morphological and tensile study of CdS/Polystyrene (PS) nanocomposite. J Res Updates Polym Sci 2013; 2: 105-9. http://dx.doi.org/10.6000/1929-5995.2013.02.02.3

[9] Luo JQ, Yang B, Cheng GJ, Xia R, Su LF, Miao JB, Qian JS, Chen $P$. Preparation and characterization of nitrile butadiene rubber (NBR)/polyoxymethlene (POM) blends compatibilized by maleic anhydride grafted POM (MAH-g-POM). J Res Updates Polym Sci 2013; 2: 97-104. http://dx.doi.org/10.6000/1929-5995.2013.02.02.2

[10] Dey K, Alamgir P, Mohol G, Parvin S, Khan MA, Khan RA Fabrication and thermo-mechanical characterization of HEMA treated UV photo-cured biodegradable chitosan film. J Res Updates Polym Sci 2014; 3: 86-96. http://dx.doi.org/10.6000/1929-5995.2014.03.02.3

[11] Lee WH, Park YD. Organic semiconductor/insulator polymer blends for high-performance organic transistors. Polym 2014; 6: 1057-73.

http://dx.doi.org/10.3390/polym6041057

[12] Chieng BW, Ibrahim NA, WMZY, Hussein MZ. Poly(lactic acid)/Poly(ethylene glycol) polymer nanocomposites: Effects of graphene nanoplatelets . Polym 2014: 6: 93-104. http://dx.doi.org/10.3390/polym6010093

[13] Parsons AJ, Evans M, Rudd CD, Scotchford CA. Synthesis and degradation of sodium iron phosphate glasses and their in vitro cell response. J Biomed Mat Res, 2004; 71: 283-91. http://doi.org/10.1002/jbm.a.30161

[14] Stepien R, Franczyk M, Pysz D, Kujawa I, Klimczak M Buczynski R. Ytterbium-phosphate glass for microstructured fiber laser. Mater 2014; $7:$ 4723-38.

http://dx.doi.org/10.3390/ma7064723

[15] Ahmed I, Lewis M, Olsen I, Knowles JC. Phosphate glasses for tissue engineering: Part 1 . Processing and characterisation of a ternary-based $\mathrm{P}_{2} \mathrm{O}_{5}-\mathrm{CaO}-\mathrm{Na}_{2} \mathrm{O}$ glass system. J Biomat 2004; 25: 491-9.

\section{http://doi.org/10.1016/S0142-9612(03)00546-5}

[16] Mavridis IM. Structural characterization of inorganic biomaterials. Biomedical Inorganic Polymers: Progress in Molecular and Subcellular Biology 2013; 54: 19-38. http://doi.org/10.1007/978-3-642-41004-8 2

[17] Dorozhkin SV. Calcium orthophosphate-based biocomposites and hybrid biomaterials. J Mater Sci 2009; 44: 234387.

http://doi.org/10.1007/s10853-008-3124-x

[18] Fedotov AYu, Komlev VS, Smirnov VV, et al. Hybrid composite materials based on chitosan and gelatin and reinforced with hydroxyapatite for tissue engineering. J Inorg Mater App Res 2011; 2: 85-90. http://doi.org/10.1134/S2075113311010072

[19] Rose JB, Pacelli S, Haj AJE, et al. Gelatin-based materials in ocular tissue engineering. Mater 2014; 7: 3106-35. http://dx.doi.org/10.3390/ma7043106

[20] Taokaew S, Seetabhawang S, Siripong P, Phisalaphong M. Biosynthesis and characterization of nanocellulose-gelatin films. Mater 2013; 6: 782-94. http://dx.doi.org/10.3390/ma6030782

[21] Khan RA, Parsons AJ, Jones IA, Walker GS, Rudd CD. Surface treatment of phosphate glass fibers by using 2hydroxyethyl methacrylate: Fabrication of poly(caprolactone) based composites. J App Poly Sci 2009; 111: 246-54. http://doi.org/10.1002/app.29050 
[22] Stol M, Smetana KJr, Korbelár P, Adam M. Poly (HEMA)collagen composite as a biomaterial for hard tissue replacement. J Clinic Mater 1993; 13: 19-20. http://doi.org/10.1016/0267-6605(93)90084-K

[23] Georgiou G, Mathieu L, Pioletti DP, et al. Polylactic acidphosphate glass composite foams as scaffolds for bone tissue engineering. J Biomed Mater Res Part B: Appl Biomat 2007; 80: 322-31.

http://doi.org/10.1002/jbm.b.30600

[24] Gul-E-Noor F, Khan MA, Ghoshal S, Mazid RA, Chowdhury SAM, Khan RA. Grafting of 2-ethylhexyl acrylate with urea onto gelatin film by gamma radiation. J Macromol Sci Part A: Pur App Chem 2009; 46: 615-24. http://doi.org/10.1080/10601320902851926

[25] Sharmin N, Khan RA, Salmieri S, Dussault D, Lacroix M. Fabrication and characterization of biodegradable composite films made of using poly(caprolactone) reinforced with chitosan. J Polym Environ 2012; 20: 698-705. http://link.springer.com/article/10.1007/s 10924-012-0431-8
[26] Yung KC, Zhu BL, Yue TM, Xie CS. Effect of the filler size and content on the thermomechanical properties of particulate aluminum nitride filled epoxy composites. J App Poly Sci 2010; 116: 225-36

http://doi.org/10.1002/app.31431

[27] Ahmad MB, Lim JJ, Shameli K, Ibrahim NA, Tay MY Synthesis of silver nanoparticles in chitosan, gelatin and chitosan/gelatin bionanocomposites by a chemical reducing agent and their characterization. Molecul 2011; 16: 7237-48. http://dx.doi.org/10.3390/molecules16097237

[28] Dey K, Khan RA, Sharmin N, Nahar S, Parsons AJ, Rudd $\mathrm{CD}$. Effect of iron phosphate glass on the physicomechanical properties of jute fabric-reinforced polypropylenebased composites. J Thermoplas Compo Mater 2011; 24: 695-711.

http://doi.org/10.1177/0892705711401848

[29] Rahman M, Dey K, Parvin F, et al. Preparation and characterization of gelatin-based PVA Film: Effect of gamma irradiation. J Polym Mater Polyme Biomat 2011; 60: 1056-69. http://doi.org/10.1080/00914037.2010.551365 